http://dx.doi.org/10.18778/1508-1117.24.05

Szymon Wiśniewski

\title{
CHANGES TO THE CENTROID OF ŁÓDŹ PROVINCE TOWNS IN THE LIGHT OF TRANSPORT POTENTIAL
}

\begin{abstract}
This article presents changes to the location of the centroid of Łódź province towns resulting from their intraregional time accessibility as well as from transformations in the potential accessibility connected with the dynamic development of road infrastructure. The research was extended through using descriptive methods of spatial statistics as well as spatial data exploratory analysis with focus on dispersion statistics in the form of standard deviation ellipse. Features of ellipses elaborated for individual moments in the development of intraregional infrastructure connections allow to define transformations of transport potential of the province's towns from the spatial perspective.
\end{abstract}

Key words Transport accessibility, Łódź Province, road infrastructure, individual transport, standard deviation ellipse.

\section{Introduction}

Levels of transport infrastructure accessibility depend, among other things, on the network's density, its structure and layout which may be described by means of diversified geographic, demographic or economic factors. High levels of transport accessibility may translate themselves into an increase in the investment attractiveness of the region in question.

Social and economic consequences of network extensions may be analysed, on the one hand, from the perspective of demand as influence on the financial situation of subcontractors and other companies operating in the vicinity of the ongoing investment, but also as social or environmental costs. They may be perceived, on the other hand, in the demand variant when it assumes the form of attracting production and service investments, fosters development of settlement and intensification of urbanization processes, triggering at times the corridor effect (Komornicki and others 2013). 
The article presents changes to time accessibility of Łódź province towns and transformations in the potential accessibility accompanying it connected with the dynamic development of road infrastructure. The research refers, in particular, to investment concerning roads with limited accessibility accomplished during the last two years. The analysis concerns a very short period of time yet it offers an opportunity to show how single but major investments alter accessibility levels (Wiśniewski 2015a).

The research was triggered by the dynamic development of new infrastructure and modernization of the existing infrastructure in the Lódź province. Hence it is necessary to conduct research which will indicate how the existing investments have influenced the location of the centroid of the region's urban settlement network in the light of transport potential. The analysis is based on measurements of journey times between the province's towns on the basis of which the study was extended by specifying changes in the transport potential of individual centres. The research is extended through the use of descriptive methods of spatial statistics as well as spatial data exploratory analysis with focus on dispersion statistics in the form of standard deviation ellipse. Features of ellipses elaborated for individual moments in the development of intraregional infrastructure connections allow to define transformations of transport potential of the province towns from the spatial perspective.

Measurements were made on the basis of journey times using the shortest journey route. At the same time a principle was adopted that measurements are made to the town's administrative border (in case of roads with unlimited accessibility) and to the first possible motorway exit if it is located within the town's borders. Journeys routes were established with the use of an application by the Emapa Company. A prerequisite was adopted while demarcating the fastest connection which says that factors determining speed of vehicles are speed limits resulting from the traffic law and the amount of traffic (due to inclusion of updated data of Traffic in the route establishment algorithm; archived data were ignored). In order to receive reliable results the research was conducted for both periods with assumptions which are supposed to make its results objective. In both cases the choice of date was motivated by weather conditions (in this way the winter period was excluded and so were the summer months with lower road traffic and weeks connected with longer breaks, such as Easter, etc.). Finally the research was conducted in May (the $13^{\text {th }}, 15^{\text {th }}, 17^{\text {th }}$ ) 2013 and April (the $20^{\text {th }}, 22^{\text {nd }}, 24^{\text {th }}$ ) 2015. Three measurements of journey times were carried out daily (in peak and off-peak hours). The research was conducted simultaneously for all possible relations between 44 towns of the Łódź province. The first measurement of journey times commenced at 7:45 a.m. considering the theoretical journey times to the administrative borders of towns. This time was adopted with the assumption that most people who tend to generate the morning transport peak go to work (school) 
for 8:00 a.m., and the time necessary to reach most places within centres of towns in the province is approximately 15 minutes (albeit it substantially varies for invididual towns). The second measurement started at 10:00 a.m. after the morning peak. The last measurement of journey times commenced at 4:15 p.m. during the afternoon peak. This alluded to the assumption adopted while making the first measurement in accordance with which 4:00 p.m. is a common hour of finishing work and it takes 15 minutes to leave town centre (Bartosiewicz, Pielesiak 2012). In total there were 18 measurements for all relations in the $44 \mathrm{x} 44$ matrix. Subsequently, the measurements conducted in May and April were averaged for each period.

The analysis presented in the article refers to research devoted to transport accessibility conducted, among others, by T. Komornicki and others (2009), P. Rosik and others (2012) or P. Śleszyński (2014). Research into accessibility from the perspective of time was also carried out by J. Gadziński (2010), R. Guzik (2012) or P. Olszewski and others (2013).

The aim of this work is to define changes to the location of the centroid of Łódź province towns in the light of transport potential resulting from infrastructural transformations. In the first part of the article alterations to journey times are presented from the topological standpoit. Subsequently, potential accessibility of urban centres in the Łódź province was scrutinised, which enabled the use of dispersion statistics in the form of standard deviation ellipse and eventual analysis of transformations in the transport and settlement network of the Łódź region.

\section{Changes to journey times}

Changes to accessibility levels of Łódź province towns from the perspective of individual transport were established on the basis of journey times by passenger car between these centres. On this stage considerations on physical distances were ignored due to their marginal importance for travellers' choices since in practice it is not infrequent that it is cost-effective to go a longer way in order to be able to achieve higher speed and accomplish transport tasks in a shorter space of time. This is when we are faced with the phenomenon of substitution, or a possibility of replacing spatial distance with time distance (Gęsiarz 1982).

The variant of analysis of journey times between Łódź province towns presented in this article assumes gross journey time, i.e. the time necessary to cover the distance between the journey starting and finishing points without any breaks (e.g. to res tor for a meal) but considering limitations (detentions) resulting from traffic organization or congestion. As a result also journeys on paid motorway sections were taken into account. In defining accessibility the shortest possible route was always sought, which did not always coincided with the shortest route as far as the real physical distance is considered. 
In spatial diversification of the volume of changes to journey times (fig. 1) it is notable to see the commissioning the whole course of the S8 expressway from the western border of the Łódź province to the node which connects it with the national way no. 1 . Topologically, the biggest changes to journey times in the time analysed can be definitely found in centres in the south-western part of the region. Reduction in the journey time to these towns from the topological perspective varies from 200 to over 400 minutes. It is also worth stressing a really distinct increase in the number of towns (in the heart of the region) whose topological time accessibility does not exceed 2000 minutes. It is precisely between these two indicated areas of the province that there are the most significant decreases in journey times in bilateral relations between urban centres. Differences reach the value which is as high as even 30 minutes.

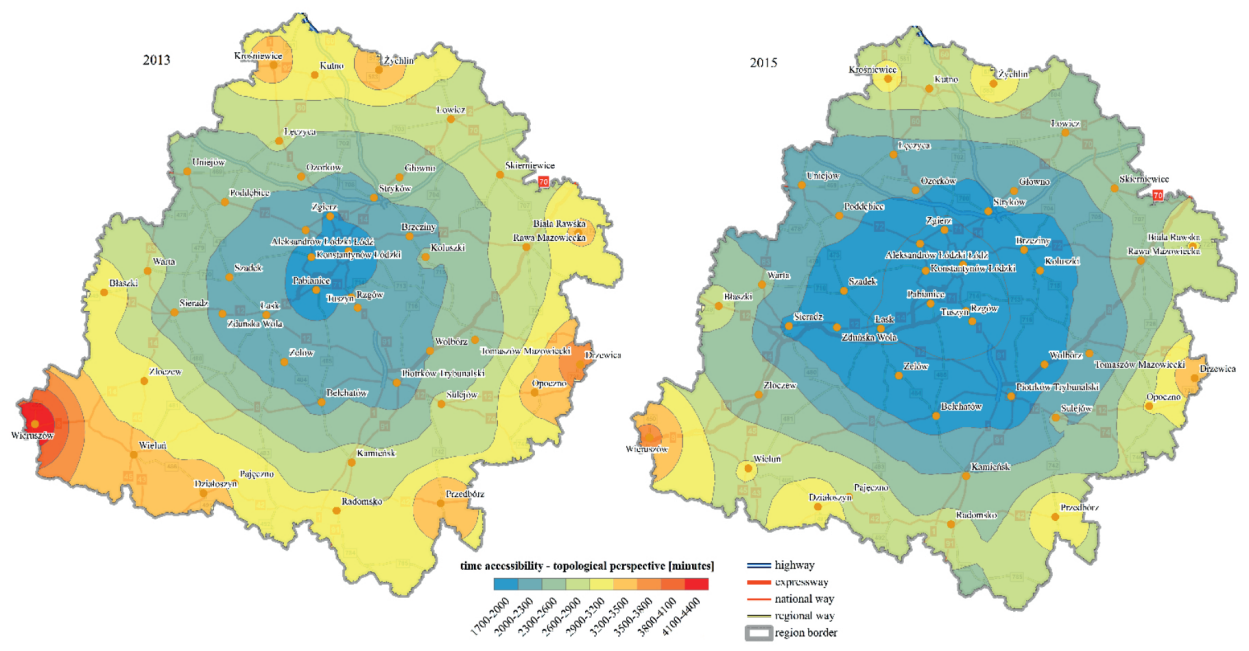

Fig. 1. Time accessibility of towns in the Łódź province in 2013 and 2015 from the topological perspective

Source: own work

The changes to journey times to Łódź province towns indicated above confirm the regularity indicated by P. Rosik (2012) that, considering conditions in Poland, the only serious anthropogenic barrier for accessibility is the state of transport infrastructure in respect to both its quality and quantity.

\section{Changes in the potential}

Numerous and intensive relations linking elements of this network give rise to synergic effects in the settlement network of the given area (Śleszyński 2009). If the aim is to increase the effectiveness of connections, it is necessary to shape them in 
such a way that their construction will enable the shortest possible connection of centres, with the readiness to handle traffic of the anticipated volume at the same time. It is then necessary to bear in mind land use component, e.g. in the form of assessment of individual centre attractiveness as potential destination. This type of research enables the use of gravity and potential analyses based on physical sciences yet effectively used in transport analyses.

An efficient transport network should be characterised by high levels of spatial effectiveness, that is economically best achievable course of connections enabling, on the one hand, maximum coverage on the given area and the shortest possible distance, on the other.

Comparison of accessibility indicators before and after investment into transport infrastructure is one of the methods of assessment of transport system effectiveness in relation to the settlement network of the given area that is used in this article. Accessibility can be understood as potential for interaction opportunities (Hansen 1959). Definition considerations are one of the main reasons why transport accessibility is definitely the most common approach in transport accessibility research. The group of models defined as potential accessibility includes different variants of accessibility measured by means of potential indicators or gravitation models. As it was mentioned above, components determining transport accessibility, the transport component and land use, are mutually connected. Potential accessibility indicators are based on the premise that attractiveness of a destination increases together with its size and decreases as the physical, time or economic distance increases (Komorniki and others 2009).

The above-mentioned W.G. Hansen (1959) was the first to refer directly to accessibility and is the most frequently cited author in the literature of the subject. The simplest indicator which he used, also referred to as Hansen's indicator, is accessibility understood as the sum of quotients of attractions (weights) of destinations and times (costs) of journeys to these destinations.

$$
A_{1}=\sum_{j} \frac{M_{j}}{c_{i j}^{\alpha}}
$$

where:

$A_{1}$ - transport accessibility of town $i$,

$M_{j}$ - weight available in town $j$,

$c_{i j}$ - aggregate time distance connected with journey from region $i$ to region $j$

while $\alpha$ is the index assuming value one.

The biggest surges in the potential in the analysed period occurred in the case of towns situated peripherally in the south-western part of the province (fig. 2), in particular in Wieruszów, Złoczew and Sieradz. It is also clear to see the area of potential growth, alluding with its shape to the course of national ways no. 8 and 12 
from the western border of the province to the town of Sulejów. At the same time one may see an almost unchanged potential in the case of centres situated in the north-eastern edges of the region. This situation may be accounted for a kind of barrier in the form of Łódź and towns which are its direct neighbours: Pabianice, Konstantynów Łódzki, Aleksandrów Łódzki and Zgierz. Individual car transport in these centres is accompanied by strong factors which reduce the smoothness and speed of trips in vehicles. Both transit and town traffic are significantly slowed down by the existing congestion combined with numerous main artery exclusions which accompany infrastructure investments. This is a particularly important factor in the adopted research variant which takes into account traffic conditions. The indicated barrier may be strong enough to level out time benefits arising from journey by expressway and is indirectly responsible for limiting the volume of potential change.

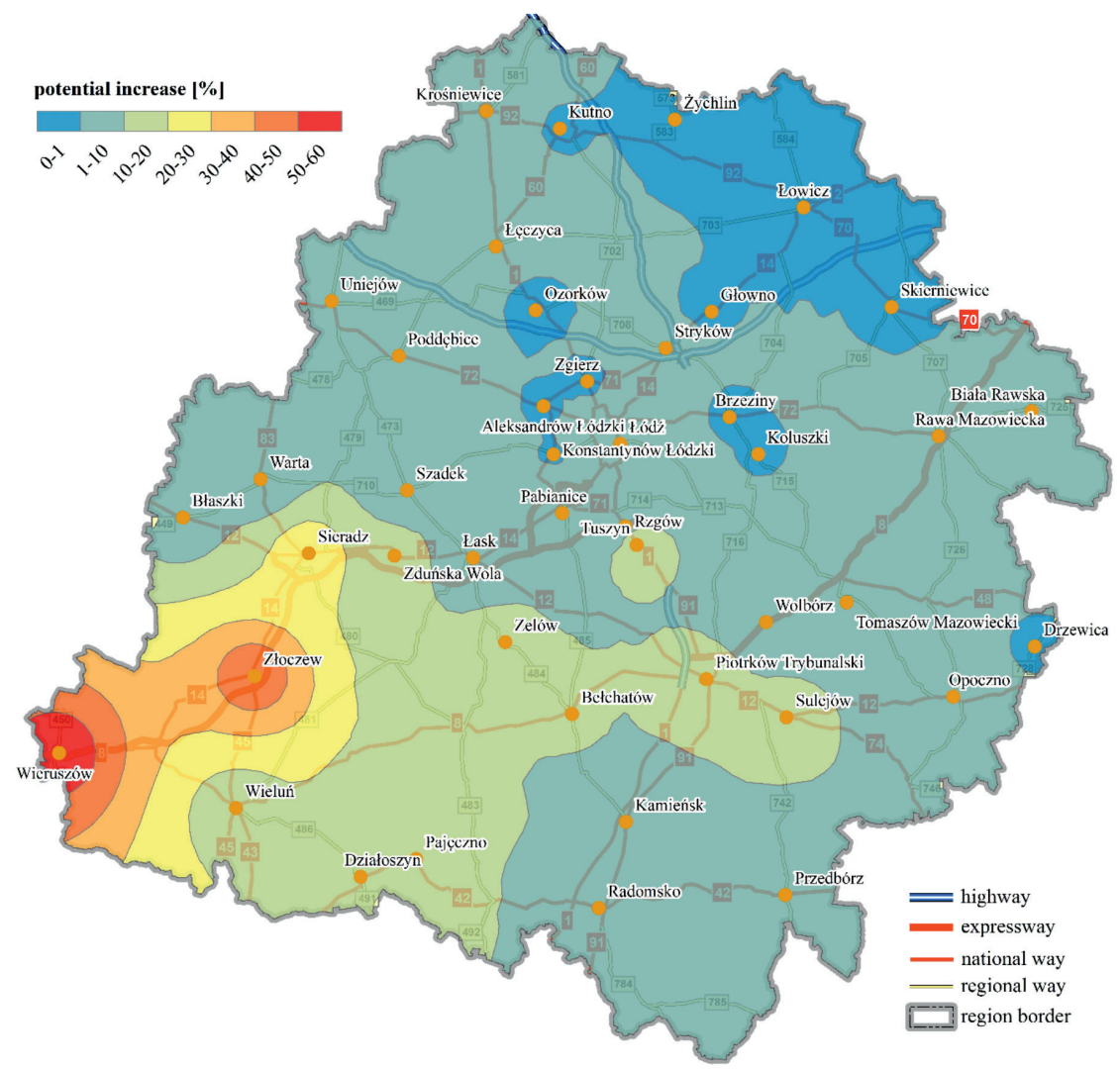

Fig. 2. Increase in the transport potential of towns in the Lódź province between 2013 and 2015

Source: own work 


\section{Changes to the centre of gravity}

The choice of statistics of central tendency and dispersion was aimed at highlighting changes in the potential as well as pointing to their spatial dimension. Centrographic measurements belong to numerous statistics characterising the distribution of points in space. They include: centre of gravity, standard deviation and standard deviation ellipse. Therefore, if a collection of towns of the Łódź province is transformed into a collection of points, then it is possible to use these measurements to analyse the distribution of towns and their transport potential. These characteristics include the geometric centre location of the collection of towns and their potential in relation to one another and the geometric centre of the region as well as the size and direction of dispersion (Jażdżewska 2006). A common application of central measurements consists in marking the optimum localisation of technical infrastructure facilities due to its relatively easy access for potential users.

To construct a standard deviation ellipse characterising the spatial distribution of urban centres it is necessary to determine the central mean $\left(\bar{x}_{\mathrm{c}}, \bar{y}_{\mathrm{c}}\right)$ of the settlement network of the Lódź province. It constitutes the centre of gravity marked on the basis of the longitude $\left(x_{i}\right)$ and the latitude $\left(y_{i}\right)$ of individual towns dispersed in the region area.

$$
\bar{x}_{\mathrm{c}}=\frac{\sum_{i=1}^{n} x_{i}}{n}, \bar{y}_{\mathrm{c}}=\frac{\sum_{i=1}^{n} y_{i}}{n}
$$

Constructing a weighted standard deviation ellipse requires defining the symmetry centre through acknowledging the volume of transport potential of individual centres through the use of centre weighted mean $\left(\bar{x}_{\mathrm{wc}}, \bar{y}_{\mathrm{wc}}\right)$. In this study mean weights $\left(p_{i}\right)$ are values of town potential (sizes in absolute terms) for 2013 and 2015.

$$
\bar{x}_{\mathrm{wc}}=\frac{\sum_{i=1}^{n} p_{i} x_{i}}{\sum_{i=1}^{n} p_{i}}, \quad \bar{y}_{\mathrm{wc}}=\frac{\sum_{i=1}^{n} p_{i} y_{i}}{\sum_{i=1}^{n} p_{i}}
$$

To draft a standard deviation ellipse, it is necessary to calculate the angle $\alpha$ of the ellipsis axis (Y) in relation to the coordinate system (axis OY) as well the length of the semi-axis of the ellipsis $\left(\sigma_{x}, \sigma_{y}\right)$. The intersection of the maximum symmetry axis and minimum symmetry axis is the graphic projection of the central mean. The connection of the intersection of the symmetry axis with the ellipsis marks the section corresponding to the standard distance. This section is the hypotenuse of the right-angled triangle in which the catheti are standard deviations of coordinates to the central mean (Suchecka 2014). 


$$
\begin{aligned}
& \operatorname{tg} \alpha=\frac{\sum x^{2}-\sum y^{\prime 2}+\sqrt{\left(\sum x^{\prime 2}-\sum y^{\prime 2}\right)^{2}+4\left(\sum x y^{\prime}\right)^{2}}}{2 \sum x^{\prime} y^{\prime}} \\
& \sigma_{\mathrm{X}}=\sqrt{\frac{\left(\sum x^{2}\right) \cos ^{2} \alpha-2\left(\sum x^{\prime} y^{\prime}\right) \sin \alpha \cos \alpha+\left(\sum y^{\prime}\right) \sin ^{2} \alpha}{n}} \\
& \sigma_{\mathrm{y}}=\sqrt{\frac{\left(\sum x^{\prime}\right) \sin ^{2} \alpha+2\left(\sum x^{\prime} y^{\prime}\right) \sin \alpha \cos \alpha+\left(\sum y^{\prime 2}\right) \cos ^{2} \alpha}{n}}
\end{aligned}
$$

where:

$$
\mathrm{x}^{\prime}=\mathrm{x}-\overline{\mathrm{x}}, \quad \mathrm{y}^{\prime}=\mathrm{y}-\overline{\mathrm{y}}
$$

Even though measurement of spatial dispersion refers to dispersion analysis in its classical form, it still requires the use of statistics which account for features connected with their location due to two-dimensionality of the described objects (towns of the Łódź province). Spatial units are neither equally nor evenly removed from the central mean. As opposed to the standard distance, the standard deviation ellipse gives an opportunity to define dispersion directions of objects in space (Kachnic 2010).

Ellipsis symmetry axes rotated by a certain angle do not only illustrate the direction of dispersion around the central mean but also the direction and size of minimum and maximum dispersion. Reduced flatness of weighted ellipses and decreased length of their axis in ellipses constructed for the Łódź province points, for instance, to a drop in transport potential in large towns in the region centre (fig. 3). These changes may indirectly indicate positive transformations of the province's transport network in relation to peripheral towns. Introducing a diagonal road allowing quick and smooth traffic results not only in moving the centre of gravity in the south-western direction but also reduces disparities in accessibility levels of the region's towns, which is reflected in clear approximation of shapes of weighted ellipses to the circle.

\section{Conclusion}

It is apparent to see changes to the location of the centroid of Lódź province towns in the analysed period resulting from infrastructure transformations in the light of transport potential. Spatial changes to journey times topologically allude to the route of a section of the newly finished Expressway no. 8, which results in slight smoothening of the shape of the isoline of equal journey time. Together with the progress of investment processes connected with the region's transport infrastructure, including both new roads and improvement of technical characte- 


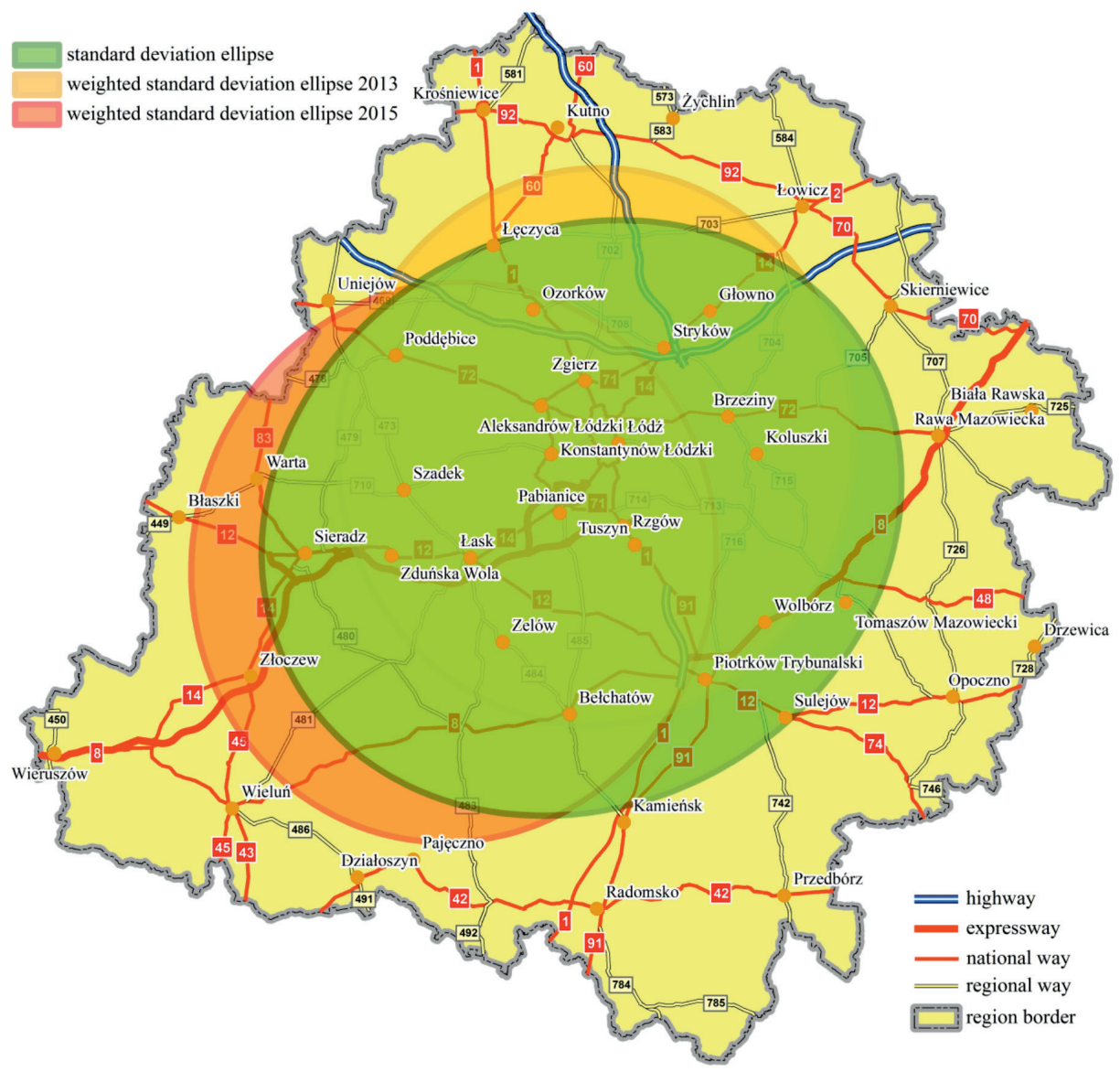

Fig. 3. Spatial scope of standard deviation ellipsis of coordinates of the Łódź region towns and standard deviation ellipsis weighted by transport potential in 2013 and 2015

Source: own work

ristics of the existing sections, the layout of isochrones marked from the centre of the region will be getting closer to the concentric one (Wiśniewski 2015b). Infrastructure transformations did not remain neutral also for the spatial diversification of potential accessibility of the region's towns. Its considerable relative changes in the short analysis period confirm the special role of roads with limited accessibility (expressways and motorways) and make us pay special attention to the process of their routing as apart from its strategic supra-regional importance they play a significant role in transport relations also within the region, affecting its local transport connections. 


\section{BIBLIOGRAPHY}

Bartosiewicz B., Pielesiak I., 2012, Powiazania transportowe w Eódzkim Obszarze Metropolitalnym (Transport Connections in the Eódź Metropolitan Area), [in:] Bartosiewicz B., Marszał T., Pielesiak I. (ed.), Spójność terytorialna Łódzkiego Obszaru Metropolitalnego, „Studia KPZK PAN”, 147, Warsaw, p. 105-137.

Gadziński J., 2010, Ocena dostępności komunikacyjnej przestrzeni miejskiej na przykładzie Poznania (Evaluation of Urban Area Transport Accessibility as Exemplified by Poznań), „Biuletyn Instytutu Geografii i Społeczno-Ekonomicznej i Gospodarki Przestrzennej UAM", 13, Bogucki Wydawnictwo Naukowe, Poznań.

Gęsiarz Z., 1982, Zarys geografii transportu (Outline of Transport Geography), WSiP, Warsaw.

Guzik R. (ed.), 2012, Czynniki i ograniczenia rozwoju miast województwa pomorskiego $w$ świetle relacji przestrzennych i dostępności komunikacyjnej (Factors and Limitations to Development of Pomerania's Towns in the Light of Spatial Relations and Transport Accessibility), The Marshal's Office of the Pomeranian Province, Gdańsk.

Hansen W.G., 1959, How Accessibility Shapes Land-use, „Journal of the American Institute of Planners", 25, p. 73-76.

Jażdżewska I., 2006, Zmiana położenia środka ciężkości miast i ludności miejskiej $w$ Polsce $w$ XX wieku (Change to the Centre of Gravity of Towns and Urban Population in Poland), „Przegląd Geograficzny”, 78(4), Warsaw, p. 561-574.

Kachnic M., 2010, Ocena rozpoznania hydrogeologicznego na przykładzie wybranego fragmentu Pojezierza Pomorskiego - Bory Tucholskie, „Biuletyn Państwowego Instytutu Geologicznego - Hydrogeologia", 442(11), s. 89-94.

Komornicki T., Śleszyński P., Rosik P., Pomianowski W., 2009, Dostępność przestrzenna jako przesłanka ksztattowania polskiej polityki transportowej (Spatial Accessibility as Prerequisite for Shaping Polish Transport Policy), „Biuletyn KPZK PAN”, 241, Warsaw.

Komornicki T., Rosik P., Śleszyński P., Solon J., Wiśniewski R., Stępniak M., Czapiewski K., Goliszek S., 2013, Wpływ budowy autostrad i dróg ekspresowych na rozwój spoteczno-gospodarczy i terytorialny Polski (Impact of Construction of Motorways and Expressways on Poland's Social, Economic and Territorial Development), Warsaw.

Local Data Bank of the Central Statistical Office of Poland (GUS), http://stat.gov.pl/bdl/ app/strona.html?p_name=indeks.

Olszewski P., Dybicz T., Śleszyński P., 2013, Proponowane miary dostępności czasowej $w$ transporcie publicznym (Proposed Measurements of Spatial Accessibility in Public Transport), „Przegląd Komunikacyjny”, 12, p. 10-17.

Rosik P., 2012, Dostępność lądowa przestrzeni Polski w wymiarze europejskim (Land Accessibility of Poland in the European Dimension), „Prace Geograficzne”, 233, IGiPZ PAN, Warsaw.

Rosik P., Stępniak M., Komornicki T., Pomianowski W., 2012, Monitoring spójności terytorialnej gmin w skali krajowej i międzynarodowej w latach 1995-2030 (Monitoring of Territorial Cohesion of Communes on a National and International Scale between 1995 and 2030), IGiPZ PAN, Warsaw. 
Suchecka J., 2014, Statystyka przestrzenna. Metody analiz struktur przestrzennych (Spatial Statistics. Methods of Spatial Structure Analysis), Warsaw.

Śleszyński P., 2009, Dostępność metropolii jako warunek konkurencyjności polskiej przestrzeni (Metropolis Accessibility as Prerequisite for Competitiveness of Polish Space), „Mazowsze - Studia Regionalne”, 2, Mazowieckie Biuro Planowania Regionalnego, Warsaw, p. 53-71.

Śleszyński P., 2014, Dostępność czasowa i jej zastosowanie (Time Accessibility and its Application), „Przegląd Geograficzny”, 86,(2), IGiPZ PAN, Warsaw, p. 171-215.

Transport Accessibility Website of IGiPZ PAN, http://www.igipz.pan.pl/accessibility/pl/ home.html.

Wiśniewski S., 2015a, Changes to Accessibility of Łódź Province Towns in Individual Transport between 2013-2015, „Przegląd Geograficzny”, Warsaw [in print].

Wiśniewski S., 2015b, Diversification of Transport Accessibility of Towns in the Eódź Province, Wydawnictwo UŁ, Łódź.

\section{ZMIANA POŁOŻENIA ŚRODKA CIĘŻKOŚCI MIAST WOJEWÓDZTWA ŁÓDZKIEGO W ŚWIETLE POTENCJALU TRANSPORTOWEGO}

Zarys treści $\quad$ W niniejszym artykule przedstawiono zmiany położenia środka ciężkości miast województwa łódzkiego wynikające $\mathrm{z}$ ich wewnątrzregionalnej dostępności czasowej oraz towarzyszących im przemian w dostępności potencjałowej związanej z dynamicznym rozwojem infrastruktury drogowej. Badanie poszerzono o zastosowanie opisowych metod statystyki przestrzennej oraz eksploracyjnej analizy danych przestrzennych ze szczególnym uwzględnieniem statystyk dyspersji w postaci elipsy odchylenia standardowego. Cechy elips wykreślonych dla poszczególnych momentów w rozwoju regionalnych powiązań infrastrukturalnych pozwalają na określenie przemian potencjału transportowego miast województwa w ujęciu przestrzennym.

Słowa kluczowe Dostępność transportowa, województwo łódzkie, infrastruktura drogowa, transport indywidualny, elipsa odchylenia standardowego.

Dr Szymon Wiśniewski

Katedra Zagospodarowania Środowiska i Polityki Przestrzennej Wydział Nauk Geograficznych, Uniwersytet Łódzki 